\title{
Paraneoplastic rheumatic disorders: a narrative review
}

\author{
C.U. Manzini, M. Colaci, C. Ferri, E. Manzini \\ Rheumatology Unit, Azienda Ospedaliero-Universitaria di Modena, Italy
}

\begin{abstract}
SUMMARY
Paraneoplastic syndromes (PS) are a heterogeneous group of diseases related to a neoplasm, indirectly dependent on it. Diagnosis and the treatment are often a challenge for clinicians, not least because the pathogenetic mechanisms are highly complex and not entirely known. Nonetheless, in most cases, PS precede the diagnosis of malignancies, thus their identification is particularly important in addressing physicians' diagnostic work-up with regard to early cancer diagnosis.

Among paraneoplastic syndromes, those of rheumatologic interest represent a large component. In this paper, we review the main rheumatic PS.
\end{abstract}

Key words: Paraneoplastic syndromes; Rheumatic diseases; Tumors.

Reumatismo, 2018; 70 (4): 199-211

\section{INTRODUCTION}

The term paraneoplastic syndrome (PS) defines a group of pathological conditions characterized by various clinical expressions (rheumatological, endocrinological, neurological, etc.) observed in the presence of a neoplasm, but not dependent on the tumor itself or its metastases.

The causative link between several neoplasms and PS is essentially supported by the fact that the surgical excision or other successful treatment of the tumor leads to improvement/resolution of the syndrome $(1,2)$.

PS encompasses many clinical-pathogenetic disorders, the nosologic classification of which is often hard because of the high heterogeneity of clinical presentation, with different and often unknown pathogenetic paths $(1,2)$. Several active substances (hormones, cytokines, enzymes) secreted by tumoral cells may trigger inflammatory processes involving a number of organs, including joints and muscles. In other cases, the immune reaction destroying neoplastic cells leads to cross-reactions against physiological antigens $(3,4)$.
In most cases, PS clinical signs can precede those directly dependent on the neoplasm; in other cases, manifestations may be simultaneous or subsequent (5). The PS of rheumatological pertinence represent the prevalent subgroup of these disorders (6). Besides the rheumatic-related PS (RPS), we underline that several autoimmune disorders constitute the favoring substrate to neoplasm development (e.g. lymphomas in rheumatoid arthritis, systemic lupus erythematosus, Sjögren's syndrome, lung cancer in scleroderma, etc.) (6).

In this narrative review, based on a selection from about 500 scientific papers, we illustrate the main RPS, considering the pathological conditions that were referred to the rheumatologist at their clinical presentation (Table I and Figure 1).

\section{HYPERTROPHIC OSTEOARTHROPATHY}

Hypertrophic osteoarthropathy (HOA) represents the prototype of RPS. The mean clinical features are:

- Hippocratic fingers (drumstick finger; watch-crystal nail) associated with skin
Corresponding author: Carlo Umberto Manzini Rheumatology Unit, Azienda Ospedaliero-Universitaria Via del Pozzo, 71 - 41100 Modena, Italy E-mail: manzini.carlo@policlinico.mo.it 
Table I - Summary of the main rheumatic paraneoplastic syndromes.

\begin{tabular}{|l|l|}
\hline Inflammatory & Hypertrophic osteoarthropathy \\
joint and & Relapsing polychondritis \\
tendon- & Secondary gout \\
diseases & Jaccoud's arthropathy \\
& Amyloid arthropathy \\
& Multicentric reticulohistiocytosis \\
& Carcinomatous polyarthritis \\
& Remitting seronegative symmetrical synovitis with pitting edema (RS3PE) \\
& Adult onset Still's disease \\
& Palmar fasciitis and polyarthritis \\
& Eosinophilic fasciitis \\
& Localized nodular myositis \\
\hline Vasculitis & Leukocytoclastic vasculitis \\
& Polyarteritis nodosa \\
& Granulomatous polyangiitis \\
& Eosinophilic granulomatosis with polyangiitis \\
& Microscopic necrotizing polyangitis \\
& Horton's giant cell arteritis \\
& Polymyalgia rheumatica \\
& Cryoglobulinemia \\
& Erythema nodosum \\
\hline Connective & Dermatomyositis/Polymyositis \\
& Systemic sclerosis \\
tissue & Systemic lupus erythematosus \\
diseases & Paraneoplastic acral vascular syndrome \\
&
\end{tabular}

thickening, which determines a spatula aspect of the hands and elephant foot at the lower extremities;

- Bone pain (not articular) worsened by movements and alleviated by rest;

- Joint involvement (arthralgias or arthritis), especially at wrists, knees and ankles;

- Vascular alterations caused by peripheral vasodilation, producing skin hyperthermia, cyanosis, and sweating of the extremities.

Primary HOA (pachydermoperiostosis) is infrequent, while the secondary form can complicate several pathological conditions, including tumors, especially bronchogenic carcinoma. In the form secondary to malignancies, regression of the syndrome can be obtained by tumor excision or chemoradiotherapy (7).

X-ray examination shows diaphyseal subperiosteal proliferation, especially of tibia, fibula, ulna, metacarpal and metatarsal

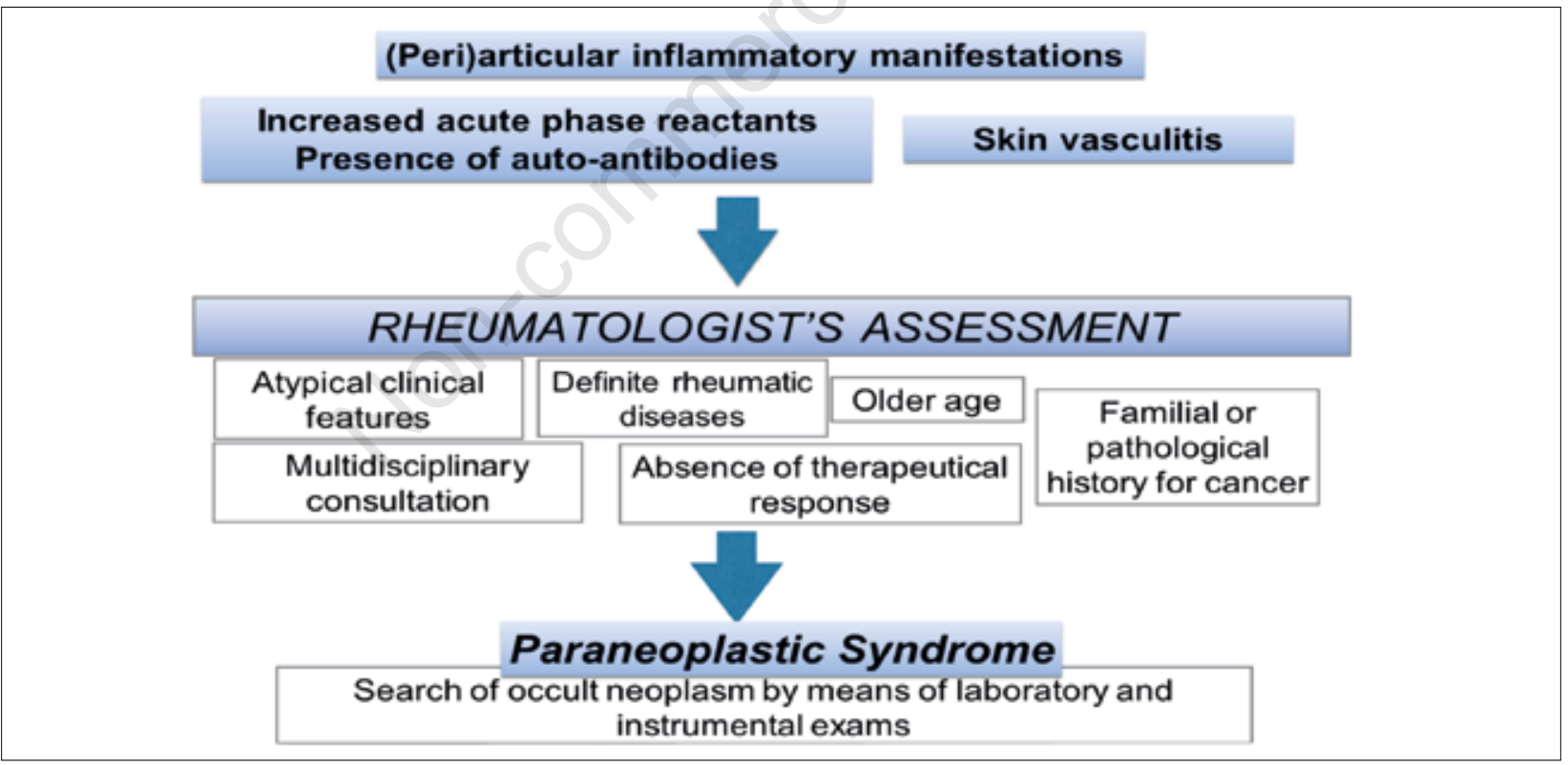

Figure 1 - Schematic representation of the rheumatologist's role in the diagnosis of paraneoplastic syndrome (PS). Intermittent or chronic articular/periarticular inflammation, skin vasculitis, panniculitis, increased acute phase reactants without infective causes, presence of autoantibodies, rheumatoid factor or cryoglobulins are clinical features that induce the suspicion of PS of rheumatic pertinence.

The rheumatologist should collect all anamnestic, clinical, laboratoristic, and instrumental data; moreover, consultations with other specialists are usually needed, especially in the cases with comorbidities and of difficult interpretation. Possible red flags for PS can be: atypical clinical features, anamnestic data indicative of an increased risk of cancer, lacking or reduced therapeutic response. On suspicion of PS, specific laboratory and instrumental examinations should be prescribed, in order to verify the presence of occult neoplasm. 
bones. Bone scintigraphy provides early diagnostic images, showing linear periosteal uptake in the long bones.

Both in primary and secondary HOA, serum levels of the vascular endothelial growth factor (VEGF) secreted by megakaryocytes and platelets (8) are higher than in healthy controls (9), suggesting a pathogenetic role of this factor.

Moreover, VEGF serum levels in secondary $\mathrm{HOA}$ were found to be higher than in primary $\mathrm{HOA}$; therefore, its increase could be due also to the tumoral cells, besides megakaryocytes and platelets (9).

Supporting the hypothesis that VEGF is involved in the pathogenesis of HOA is the fact that osteogenesis is strictly dependent on angiogenesis (10); furthermore, VEGF in vitro is a strong promoter of osteoblast differentiation (11).

Extra-articular HOA features, too, suggest the pathogenetic role of VEGF, since this cytokine induces neoangiogenesis, leading to the accumulation of extracellular matrix and typical edema of the skin in HOA patients (9). Finally, HOA signs may be reduced by treatment with octreotide, a VEGF inhibitor (12).

\section{RELAPSING POLYCHONDRITIS}

Relapsing polychondritis (RP) is a rare autoimmune disease characterized by recurrent inflammation of the cartilaginous tissues, particularly in the nose, ears, larynx, and trachea. Its etiology is still unclear; the presence of antibodies directed against II type collagen was proposed (13-16).

Diagnosis is based on the presence of ascertained inflammatory episodes in at least two of the three chondral sites (ear, nose, larynx/trachea), associated with two or more manifestations among ocular inflammation, hearing loss, vestibular dysfunction and seronegative arthritis (17). Articular involvement may be represented by arthralgias, episodic, migrant, asymmetrical and non-erosive polyarthritis, sometimes with the characteristics of rheumatoid arthritis. The joints of the hands, knees and ankles are most frequently involved (18). Some cases of RP were reported in relation to hematological malignancies (leukemia, lymphoma), myelodysplasia (19-22) and, more rarely, solid tumors (breast, colon, lung, pancreas and others) $(17,23,24)$.

\section{LAMBERT=EATON SYNDROME}

The Lambert-Eaton myasthenic syndrome is an autoimmune disease characterized by defective acetylcholine release in the neuro-muscular junctions, caused by autoantibodies against the voltage-gate calcium channels, onto the presynaptic terminals of the autonomic neurons. The cardinal clinical features are myalgia, muscle weakness, especially of the lower limbs, associated with abnormal sweating, orthostatic hypotension and sexual impotence (25). Diplopia, drooping of eyelids, and dysphagia are often reported (26).

This syndrome can precede or present simultaneously to a malignancy, mainly a small cell lung carcinoma or other tumors (lymphoproliferative disorders, carcinoma of breast, colon, stomach, kidney, bladder, pancreas and prostate) (27-29) or autoimmune diseases [e.g. thyroiditis, systemic lupus erythematosus (SLE), Sjögren's syndrome, scleroderma, coeliac disease] (26).

\section{SECONDARY GOUT}

An increased cell nucleic acid degradation in patients affected by myelo-lymphoproliferative disorders or solid tumors treated with radiation or antiblastic therapy may induce hyperuricemia, responsible for secondary gout (30-34).

Secondary gout differs from the primary form, since it presents later in life, is not present in relatives and affects both sexes; moreover, it is associated with high uric acid blood levels (more than $12 \mathrm{mg} / \mathrm{dL}$ ). Finally, it more frequently involves the large joints such as the shoulders and the knees (30).

\section{AMYLOID ARTHROPATHY}

Amyloidosis is characterized by insoluble low-molecular-weight protein deposition, called amyloid, in the extracellular com- 
partment of many organs; this compromises the organ functions, with subsequent different pathologic conditions.

The polyarthropathy dependent on amyloid storage in the synovial membrane and periarticular tissues typically involves the shoulders, the knees and the wrists (31). Arthritis, often asymmetrical and not so painful (35), may be associated with multiple myeloma (36) and, less frequently, with Waldenstrom's macroglobulinemia $(31,37-39)$.

\section{REMITTING SERONEGATIVE SYMMETRICAL SYNOVITIS WITH PITTING EDEMA}

Remitting seronegative symmetrical synovitis with pitting edema (RS3PE) is a disorder which can manifest as a primary syndrome or associated with different diseases, including malignancies (40-42). RS3PE, more frequently described in elderly men, is characterized by asymmetric arthritis, mainly involving metacarpophalangeal and proximal interphalangeal joints, wrists, shoulders and extensor tendons, with edema of both hands (boxing glove hands) $(40,43,44)$; the inflammation may be easily documented by means of ultrasounds or magnetic resonance $(42,44)$.

In most cases, a marked increase of acutephase reactants is observed, while the rheumatoid factor is negative (44).

RS3PE was described in association with different solid tumors (stomach, colon, prostate, ovary and endometrium) $(40,45)$, as well as with malignant homeopathies (leukemia, non-Hodgkin lymphomas, myelodysplasia) (40, 43, 45-47).

\section{ADULT ONSET STILL'S DISEASE}

Adult onset Still's disease is a rare disease very similar to the juvenile form. It is characterized by high persistent or intermittent fever $>39^{\circ} \mathrm{C}$, evanescent macular or maculopapular skin rash of the trunk and extremities, arthralgias or arthritis, possibly associated with pharyngitis, lymphadenopathies, hepatosplenomegaly, anemia, neutrophilic lymphocytosis and liver dysfunction $(48,49)$.

Some cases of association with solid tumors, like pharyngeal epidermoid cancer (50), cancer of the lung (51), breast (52), thyroid (53), esophagus (54) and malignant hemopathies (leukemia, angioimmunoblastic lymphadenopathy and myeloproliferative syndrome) $(50,55)$ are reported.

\section{VASCULITIS}

Vasculitides are a heterogeneous group of autoimmune diseases defined by an inflammatory and necrotic process involving the vessel walls of arteries or veins of various sizes, throughout the body. This large group of diseases encompasses primary and secondary forms; the latter include diseases in which the vessel damage depends on malignancies (56). The most frequent vasculitides found in the course of cancers are leukocytoclastic vasculitis and polyarteritis nodosa $(42,57)$. The former involves the small caliber vessels and is characterized by skin lesions (palpable purpura), mainly localized at the lower limbs (including ankles and feet); systemic symptoms (fever, myalgias, arthralgias) may be associated, without visceral vasculitic involvement (58).

Regarding the pathogenesis, some authors suggest the involvement of tumoral antigens in the context of circulating immune-complexes, which deposit in the vessel walls, activating the complement cascade, thus triggering the inflammatory process (59).

Articular involvement can be characterized by mere arthralgias; in other cases, knee and ankles arthritis are described, but all joints can be involved (60).

Leukocytoclastic vasculitis was reported in association with lymphoproliferative disorders, including acute and chronic leukemias (61-68), lymphomas (69-71), myelodysplasias $(67,72,73)$, as well as solid tumors (74-77).

Polyarteritis nodosa $(\mathrm{PN})$ is a necrotizing vasculitis of small and medium vessels of multiple organs, especially the kidneys; clinically, signs and symptoms are variable. In the early stages, fatigue, weight 
loss, arthralgias or arthritis (hands, knees), skin vasculitis (palpable purpura), up to ulcers were noticed; moreover, peripheral neuropathy (asymmetric, sensitive and motor), necrotizing glomerulonephritis leading to hypertension, gastrointestinal ischemia (mesenteric vessel infarction) may develop (78-90).

Paraneoplastic PN was described in association with different solid neoplasms of the liver (76), colon (77), bladder (79), lung (80), hypopharynx (81) and hematologic diseases, namely leukemia $(4,65,82,83$, $85,86)$ and myelodysplasia $(65,87)$.

ANCA-associated vasculitis has also been related to neoplastic diseases (78).

Lastly, Horton arteritis, giant cell vasculitis primarily involving the branches of the aorta, especially extracranial vessels (particularly the temporal arteries), can be associated with solid tumors or malignant hemopathies (e.g. myelodysplasia) as a PNS (89-93).

\section{CARCINOMATOUS POLYARTHRITIS}

Carcinomatous polyarthritis $(\mathrm{CP})$ is a rare acute paraneoplastic disorder of the elderly, commonly characterized by asymmetric arthritis of the large joints of the lower limbs $(42,94)$. Moreover, general malaise and fever are experienced. Serological inflammation indexes are increased; anemia is common, while RF and anti-CCP are negative $(40,95)$. Histologic examination of synovial biopsy reveals nonspecific synovitis. The differential diagnosis includes late-onset rheumatoid arthritis. CP has been reported with several solid tumors of the stomach (96), colon (97), lung (97), pancreas (98), breast (99), larynx (100), ovaries (101), as well as lymphoproliferative disorders, such as leukemia $(102,103)$. In any case, in the presence of an elderly patient with the above clinical features, especially if not responding to conventional treatments, an underlying malignancy should be suspected.

\section{EOSINOPHILIC FASCIITIS}

Eosinophilic fasciitis (EF) is a rare disease characterized by scleroderma-like lesions mainly involving the limbs. Fibrosis and inflammatory injury involving the deep subcutaneous tissue and the fascia are characteristic $(104,105)$. The clinical picture is represented by pain, swelling and reduced function of the limbs, due to thickened skin limbs lesions, which spare the extremities. In the involved areas, the skin is inelastic and thickened, evolving into dimpling or peau d'orange appearance. Some patients experience arthritis, sometimes with erosive evolution, tenosynovitis, and periostitis of the long bones (106-109). The most relevant laboratory findings are hyper-eosinophilia, hypergammaglobulinemia, and increased erythrocyte sedimentation rate. EF can be classified as PNS when associated with malignant diseases, especially hematologic (myeloproliferative disorders, leukemia) (108, 110-112).

\section{JACCOUD'S ARTHROPATHY}

Jaccoud's disease is a deforming, not erosive, arthritis, which mainly involves the joints of the hands. We generally observe ulnar deviation with bilateral flexion deformities at the MCP joints, hyperextension at PIP and muscle wasting (swan neck finger deformities) (56, 113). Firstly described in the course of rheumatic fever or systemic lupus erythematosus, it has also been reported with lung mesothelioma (114, 115). Unlike carcinomatous polyarthritis, it presents an insidious onset, absence of pain and joint swelling, symmetrical involvement and predilection of the joints of the hands and prominent deformities of the fingers (57).

\section{CRYOGLOBULINEMIA}

Cryoglobulins are immunoglobulins which precipitate in the serum at a temperature below $37^{\circ} \mathrm{C}$ and return into solution with rewarming. Three types of cryoglobulins have been identified $(115,116)$ : type $I$ is characterized by a single monoclonal Ig (IgM, IgG, IgA) or, more rarely, by a single light chain; type II (mixed cryoglobulinemia) is characterized by monoclonal IgM and polyclonal or oligoclonal IgG; type III 
occurs where the cryoprecipitate is represented by polyclonal IgG, IgA and IgM. Cryoglobulins may induce organ damage in two main ways: blood hyperviscosity (especially in type I); type II-III immunemediate reactions (117).

Monoclonal cryoglobulinemia is mostly associated with hemopathies, such as Waldenstrom's granulomatosis, multiple myeloma or chronic lymphatic leukemia and is frequently asymptomatic $(118,119)$. Mixed cryoglobulinemia (MC) is determined by the deposition of circulating immune complexes (cryoglobulins and complement) in the small and medium size vessels (120). $\mathrm{MC}$, which recognizes $\mathrm{HCV}$ as the main etiological factor, is clinically characterized by the classic trio of purpura, asthenia, arthralgias and by the involvement of one or more organs (cutis, liver, kidney, peripheral nerves, joints); it should be noted that MC presents high risk of developing non-Hodgkin lymphoma (121).

\section{PALMAR FASCIITIS}

This syndrome is represented by fibrosis of the palmar fascia, with a following progressive hand finger flexion (claw hands); upper limbs polyarthritis may be associated. The disease, which often rapidly progressive, has been described in patients affected by ovarian carcinoma (122) and subsequently in other malignancies (breast, uterus, prostate, lung, pancreas, stomach, etc.) $(40,123)$, along with other non-tumoral diseases (tuberculosis, thyroiditis and benign ovarian cysts) (94).

\section{ERYTHEMA NODOSUM}

Erythema nodosum is a localized vasculitis involving dermal and subcutaneous tissue vessels on the legs. The typical manifestations of this disease are multiple nodules which are painful and sometimes confluent. Frequently, arthralgias or arthritis of the knees and ankles can be associated. The vasculitic process can be observed in association with several disorders, including solid tumors and hematologic malignancies (78).

\section{POLYMYALGA RHEUMATICA}

Polymyalgia rheumatica (PMR) is a typical disorder of the elderly, characterized by pain and stiffness of the shoulder and pelvic girdles, impairment of general conditions, increased serological acute phase reactants and prompt response to steroid therapy. Malignancies may clinically manifest as PMR (124, 125); significantly, PMR with one or more atypical features may represent the first clinical manifestation of a diffused cancer (94).

Atypical features of PMR are an onset age of $<50$ years, incomplete or asymmetrical involvement at the typical PMR sites, an erythrocyte sedimentation rate lower than $50 \mathrm{~mm} / 1 \mathrm{~h}$ or greater than $100 \mathrm{~mm} / 1 \mathrm{~h}$, partial or delayed (after $>48$ hours) improvement with $10 \mathrm{mg} /$ day of prednisone (94). An atypical PMR may appear 1 to 13 months before the diagnosis of cancer (126).

The association between typical PMR and malignancies is still discussed (42). The most frequent tumors observed in the course of PMR include cancer of the kidney, lung, colon and those related to hematopoietic system $(25,42,127,128)$.

In any case, since an atypical PMR may represent the first indirect manifestation of a cancer, a screening in order to look for a possible occult neoplasia should be considered (95).

\section{LOCALIZED NODULAR MYOSITIS}

Localized nodular myositis is a rare disorder characterized by a rapidly enlarging nodular inflammatory mass, usually affecting a single muscle (129-131). In a few cases, this disorder has been described as PNS (132-134).

\section{MULTICENTRIC RETICULOHISTOCYTOSIS}

Multicentric reticulohistiocytosis is a rare multisystemic disease, of unknown etiology, characterized by histiocytes and multinucleated giant cells tissue infiltration into the synovium or the skin (135). Clinically, papulonodular eruption at the ears, nose, 
scalp, back of the hands, forearms and elbows is present; in $50 \%$ of patients mucous papules at the lips, mouth, tongue, nose, pharynx and larynx are found (136). Joint involvement may occasionally show a destructive and mutilating aspect (137) at the IP of the hand fingers, wrists, shoulders, hips, knees, feet, spine and temporal-mandibular joints (138). Many other organs, such as bones, liver, salivary glands, lymph nodes, heart and lungs, may be affected (137-140). Multicentric reticulohistiocytosis may be associated with TB, hypothyroidism, diabetes, cancer of the lung (141), stomach (142), breast (143), cervix (144), colon (145), ovary (146), and malignant lymphoma (147-149).

\section{PARANEOPLASTIC RAYNAUD'S PHENOMENON (PARANEOPLASTIC ACRAL VASCULAR SYNDROME]}

Paraneoplastic Raynaud's phenomenon has been reported in literature, though rarely (150). The appearance of Raynaud's phenomenon in a patient aged over 50, presenting an asymmetrical involvement of the fingers with digital necrosis, must induce the diagnostician to consider the presence of an underlying neoplasia, especially at the gastrointestinal system and the lung (42). The typical clinical manifestation of secondary Raynaud may be similar to the primary phenomenon, although an asymmetric pattern with a tendency towards gangrene suggest a PNS (151). Association with many carcinomas, sarcomas, lymphomas and leukemias has been reported (152). It can develop at any stage of the neoplastic disease and may represent the presenting symptom $(152,153)$; furthermore, it may be a surrogate activity marker of the disease, improving after the favorable treatment of the underlying malignant condition $(154,155)$.

\section{AUTOIMMUNE DISEASES}

The activation of autoimmune mechanisms during a neoplastic disease may promote the development of a rheumatic syndrome, through the synthesis of antibodies directed against various self-antigens, including those expressed by tumor cells (156).

\section{DEMATOMYOSITIS/ POLYMYOSITIS}

Polymyositis (PM) and dermatomyositis (DM) are two connective tissue diseases characterized by muscle inflammation, with cutaneous lesions forming DM. Increased incidence of malignancies has been described in the course of PM/DM: squamous cell carcinomas (head, neck, esophagus and cervix); adenocarcinomas (stomach, colorectal, pancreas, thyroid, breast, ovary, uterus and prostate); hematopoietic and lymphoid malignancies (nonHodgkin's lymphoma, Hodgkin's lymphoma, multiple myeloma and leukemia) (157). The relationship between cancer and myositis is not entirely known. However, in some patients we can find a close temporal correlation (about 1 year) between the occurrence of a DM and the discovery of a cancer, which suggests the presence of a paraneoplastic association $(58,158-161)$.

\section{SYSTEMIC SCLEROSIS}

Skin lesions similar to those present in systemic sclerosis (SSc) have been found in patients with malignant tumors and other diseases, defined by the terms pseudoscleroderma or pseudosclerosis $(162,163)$. Lung, breast and stomach cancer, plasmacytoma and carcinoids can be associated with this PNS (163-166).

Regarding lung cancer, the release of biochemical mediators, such as hormones and growth factors, may represent the probable pathogenetic mechanism underlying skin sclerosis (167). In several cases it is necessary to differentiate SSc from a PNS (166); the latter is more probable in the case of history of cancer, exposure to carcinogens, onset of symptoms in elderly people, systemic symptoms (fever, fatigue, weight loss) (166). SSc itself, in some patients, shows a close temporal relationship with a diagnosis of cancer; in these cases, a common trigger and/or predisposing back- 
ground for both $\mathrm{SSc}$ and the cancer might be suspected $(57,168)$.

\section{SYSTEMIC LUPUS ERYTHEMATOSUS}

An SLE-like syndrome has been described in association with malignancies. A syndrome characterized by non-deforming arthritis, polyserositis, glomerulonephritis and Raynaud's phenomenon, has been related to breast, lung and ovary cancer, as well as leukemias and lymphomas $(31,40$, 169-176). Positive ANA and anti-DNA or anti-phospholipid antibodies have been detected $(40,57)$.

\section{OSTEOMALACIA}

Osteomalacia may occur during cancer; several cases have been reported in literature of the syndrome named tumor-induced osteomalacia (TIO) or organic osteomalacia (177).

It is characterized by hypophosphatemia, hyperphosphaturia, normal or low levels of 1.25-dihydroxy-vitamin $\mathrm{D}$, pathologic fractures, muscle weakness, height loss (178).

Phosphaturic mesenchymal tumor is the neoplasm most frequently associated with TIO, with production of the endocrine fibroblast growth factor 23 (FGF23, responsible for increased renal excretion in phosphate). Other tumors, such as hemangiopericytoma, osteosarcoma, giant cell tumor and other mesenchymal tumours have been described in association with TIO $(177,179)$.

\section{CONCLUSIONS}

A number of pathological conditions generally defined as for referral to rheumatology may actually be the consequence of occult cancer. These syndromes, named PNS, often share differences from the respective primary form, because of the presence of atypical features.

Therefore, PNS should be suspected in elderly patients, whose clinical symptoms, laboratory/instrumental findings, or therapeutic response diverge from what is usually expected.
In any case, on suspicion of PNS, we suggest a deepened clinical-instrumental work-up and a close follow-up, in order to verify the diagnosis of suspected cancer.

\section{REFERENCES}

1. Manzini E. Le sindromi paraneoplastiche ad impronta reumatologica. In: Cervini C. Manuale di Reumatologia. Torino: Ed. UTET. 1996; 123.

2. Consoli G. Sindromi paraneoplastiche. In: Carcassi U. Trattato di Reumatologia. Roma: S.E.U. 1993; 1743.

3. Naschitz JE, Yeshurun D, Rosner I. Rheumatic manifestations of occult cancer. Cancer. 1995; 75: 2954-8.

4. Ashouri JF, Daikh DI. Rheumatic manifestations of cancer. Rheum Dis Clin North Am. 2011; 37: 489-505.

5. Szekanecz E, Szucs G, Szekanecz Z, et al. Tumor-associated antigens in systemic sclerosis and systemic lupus erythematosus: associations with organ manifestations, immunolaboratory markers and disease activity indices. $\mathrm{J}$ Autoimmun. 2008; 31: 372-6.

6. Marmur R, Kagen L. Cancer-associated neuromusculoskeletal syndromes. Recognizing the rheumatic-neoplastic connection. Postgrad Med. 2002; 111: 95-8, 101-2.

7. Möhle R, Green D, Moore MA, et al. Constitutive production and thrombin-induced release of vascular endothelial growth factor by human megakaryocytes and platelets. Proc Natl Acad Sci USA. 1997; 94: 663-8.

8. Silveira LH, Martínez-Lavín M, Pineda C, et al.Vascular endothelial growth factor and hypertrophic osteoarthropathy. Clin Exp Rheumatol. 2000; 18: 57-62.

9. Harada S, Nagy JA, Sullivan KA, et al. Induction of vascular endothelial growth factor expression by prostaglandin E2 and E1 in osteoblasts. J Clin Invest. 1994; 93: 2490-6.

10. Midy V, Plouët J. Vasculotropin/vascular endothelial growth factor induces differentiation in cultured osteoblasts. Biochem Biophys Res Commun. 1994; 199: 380-6.

11. Maroto AAM, Martínez-Quintana E, SuárezCastellano L, Pérez-Arellano JL. Painful hypertrophic osteoarthropathy successfully treated with octreotide. The pathogenetic role of vascular endothelial growth factor (VEGF). Rheumatology (Oxford). 2005; 44: 1326-7.

12. Staalman CR, Umans U. Hypertrophic osteoarthropathy in childhood malignancy. Med Pediatr Oncol. 1993; 21: 676-9.

13. Yang CL, Brinckmann J, Rui HF, et al. Autoantibodies to cartilage collagens in relapsing polychondritis. Arch Dermatol Res. 1993; 285: 245-9.

14. Fujimoto N, Tajima S, Ishibashi A, et al. Acute 
febrile neutrophilic dermatosis (Sweet's syndrome) in a patient with relapsing polychondritis. Br J Dermatol. 1998; 139: 930-1.

15. Foidart JM, Abe S, Martin GR, et al. Antibodies to type II collagen in relapsing polychondritis. N Engl J Med. 1978; 299: 1203-7.

16. Ebringer R, Rook G, Swana GT, et al. Autoantibodies to cartilage and type II collagen in relapsing polychondritis and other rheumatic diseases. Ann Rheum Dis. 1981; 40: 473-9.

17. Michet CJ Jr, McKenna CH, Luthra HS, O'Fallon WM. Relapsing polychondritis. Survival and predictive role of early disease manifestations. Ann Intern Med. 1986; 104: 74-8.

18. Bambara LM. Policondrite ricorrente. In: Carcassi U. Trattato di Reumatologia. Vol. II, pp 1385.

19. Bochtler T, Hensel M, Lorenz HM, et al. Chronic lymphocytic leukaemia and concomitant relapsing polychondritis: a report on one treatment for the combined manifestation of two diseases. Rheumatology (Oxford). 2005; 44: 1199.

20. Miller SB, Donlan CJ, Roth SB. Hodgkin's disease presenting as relapsing polychondritis. A previously undescribed association. Arthritis Rheum. 1974; 17: 598-602.

21. Van Besien K, Tricot G, Hoffman R. Relapsing polychondritis: a paraneoplastic syndrome associated with myelodysplastic syndromes. Am J Hematol. 1992; 40: 47-50.

22. Hebbar M, Brouillard M, Wattel E, et al. Association of myelodysplastic syndrome and relapsing polychondritis: further evidence. Leukemia. 1995; 9: 731-3.

23. Jouanique C, Herreman G. Chronic atrophic polychondritis associated with cancer. Presse Med. 1989; 18: 1080.

24. Odkvist L. Relapsing polychondritis. Acta Otolaryngol. 1970; 70: 448-54

25. Naschitz JE, Rosner I, Rozenbaum M, et al. Rheumatic syndromes: clues to occult neoplasia. Semin Arthritis Rheum. 1999; 29: 43-55.

26. Seneviratne U, de Silva R. Lambert-Eaton myasthenic syndrome. Postgrad Med J. 1999; 75: 516-20.

27. Delahunt B, Abernethy DA, Johnson CA, Nacey JN. Prostate carcinoma and the Lambert-Eaton myasthenic syndrome. J Urol. 2003; 169: 278-9.

28. Collins DR, Connolly S, Burns M, et al. Lambert-eaton myasthenic syndrome in association with transitional cell carcinoma: a previously unrecognized association. Urology. 1999; 54: 162.

29. Agarawal SK, Birch BR, Abercrombie GF. Adenocarcinoma of the prostate and Eaton-Lambert syndrome. A previously unreported association. Scand J Urol Nephrol. 1995; 29: 351-3.

30. Zoppini A, Taccari E. Artriti da microcristalli. In: Carcassi U. Trattato di Reumatologia. Vol II. Roma: S.E.U. Ed. 1993; 1445.
31. Caldwell DS, McCallum RM. Rheumatologic manifestations of cancer. Med Clin North Am. 1986; 70: 385-417.

32. Krakoff IH. Studies of uric acid biosynthesis in the chronic leukemias. Arthritis Rheum. 1965; 8: 772-9.

33. Yü TF. Secondary gout associated with myeloproliferative diseases. Arthritis Rheum. 1965; 8: 765-71.

34. Ultmann JE. Hyperuricemia in disseminated neoplastic disease other than lymphomas and leukemias. Cancer. 1962; 15: 122-9.

35. Fam AG, Lewis AJ, Cowan DH. Multiple myeloma and amyloid bone lesions complicating rheumatoid arthritis. J Rheumatol. 1981; 8: 845-50.

36. Alpay N, Artim-Esen B, Kamali S, et al. Amyloid arthropathy mimicking seronegative rheumatoid arthritis in multiple myeloma: case reports and review of the literature. Amyloid. 2009; 16: 226-31.

37. Fujishima M, Komatsuda A, Imai H, et al. Amyloid arthropathy resembling seronegative rheumatoid arthritis in a patient with IgDkappa multiple myeloma. Intern Med. 2003; 42: 121-4.

38. Goldberg LS, Fisher R, Castronova EA, Calabro JJ. Amyloid arthritis associated with Waldenstrom's macroglobulinemia. N Engl J Med. 1969; 281: 256-7.

39. Hickling P, Wilkins M, Newman GR, et al. A study of amyloid arthropathy in multiple myeloma. Q J Med. 1981; 50: 417-33.

40. Marengo MF, Suarez-Almazor ME, Lu H. Neoplastic and paraneoplastic synovitis. Rheum Dis Clin North Am. 2011; 37: 551-72.

41. Cantini F, Salvarani C, Olivieri I. Paraneoplastic remitting seronegative symmetrical synovitis with pitting edema. Clin Exp Rheumatol. 1999; 17: 741-4.

42. Chakravarty E, Genovese MC. Rheumatic syndromes associated with malignancy. Curr Opin Rheumatol. 2003; 15: 35-43.

43. Olivé A, del Blanco J, Pons M, et al. The clinical spectrum of remitting seronegative symmetrical synovitis with pitting edema. The Catalán Group for the Study of RS3PE. J Rheumatol. 1997; 24: 333-6.

44. Pipitone N, Pitzalis C. Poliartrite subacuta edematosa benigna dell' anziano. Recenti Progr Med. 2004; 95: 9.

45. Paira S, Graf C, Roverano S, Rossini J. Remitting seronegative symmetrical synovitis with pitting oedema: a study of 12 cases. Clin Rheumatol. 2002; 21: 146-9.

46. Sibilia J, Friess S, Schaeverbeke T, et al. Remitting seronegative symmetrical synovitis with pitting edema (RS3PE): a form of paraneoplastic polyarthritis? J Rheumatol. 1999; 26: 115-20.

47. Roldan MR, Martinez F, Roman J, Torres A. 
Non-Hodgkin's lymphoma: initial manifestation. Ann Rheum Dis. 1993; 52: 85-6.

48. Larson EB. Adult Still's disease. Evolution of a clinical syndrome and diagnosis, treatment, and follow-up of 17 patients. Medicine (Baltimore). 1984; 63: 82-91.

49. Reginato AJ, Schumacher HR Jr, Baker DG, et al. Adult onset Still's disease: experience in 23 patients and literature review with emphasis on organ failure. Semin Arthritis Rheum. 1987; 17: 39-57.

50. Cabane J, Lebas J, Wattiaux MJ, Imbert JC. Pseudo-Still disease and neoplasm. 2 cases. Rev Med Interne. 1988; 9: 81-4.

51. Del Paine DW, Leek JC. Still's arthritis in adults: disease or syndrome? J Rheumatol. 1983; 10: 758-62.

52. Rogues AM, Vidal E, Boudinet F, et al. Breast cancer with systemic manifestations mimicking Still's disease. J Rheumatol. 1993; 20: 1786-7.

53. Ahn JK, Oh JM, Lee J, et al. Adult onset Still's disease diagnosed concomitantly with occult papillary thyroid cancer: paraneoplastic manifestation or coincidence? Clin Rheumatol. 2010; 29: 221-4.

54. Shibuya Y, Matuo K, Kawada T, et al. Adult onset Still's disease associated esophageal cancer: a case report. Ryumachi. 2003; 43 : 577-82.

55. Luzar MJ, Sharma HM. Leukemia and arthritis: including reports on light, immunofluorescent, and electron microscopy of the synovium. J Rheumatol. 1983; 10: 132-5.

56. Kurzrock R, Cohen PR. Vasculitis and cancer. Clin Dermatol. 1993; 11: 175-87.

57. Fam AG. Paraneoplastic rheumatic syndromes. Baillieres Best Pract Res Clin Rheumatol. 2000; 14: 515-33.

58. Jennette JC, Falk RJ. Small-vessel vasculitis. N Engl J Med. 1997; 337: 1512-23.

59. Ashouri JF, Daikh DI. Rheumatic manifestations of cancer. Rheum Dis Clin North Am. 2011; 37: 489-505.

60. Colombo B, Sinigaglia L. Reumatologia. Roma: Cortina Ed.; 1989.

61. Mc Combs RP. Systemic "allergic" vasculitis: clinical and pathological relationships. JAMA 1965; 194: 1059-64.

62. Farcet JP, Weschsler J, Wirquin V, et al. Vasculitis in hairy-cell leukemia. Arch Intern Med. 1987; 147: 660-4.

63. Fernandez AM, Abeles M, Wong RL. Recurrent leukocytoclastic vasculitis as the initial manifestation of acute myelomonocytic leukemia. J Rheumatol. 1994; 21: 1972-4.

64. Christianson HB, Fine RM. Vasculitis with or without panniculitis in leukemia, lymphoma, and multiple myeloma. South Med J. 1967; 60: 567-72.

65. Hasler P, Kistler H, Gerber H. Vasculitides in hairy cell leukemia. Semin Arthritis Rheum. 1995; 25: 134-42.

66. Farrell AM, Gooptu C, Woodrow D, et al. Cutaneous lymphocytic vasculitis in acute myeloid leukaemia. Br J Dermatol. 1996; 135: 471-4.

67. Beylot J, Malou M, Doutre MS, et al. Leukocytoclastic vasculitis and malignant hematologic diseases (12 cases). Rev Med Interne. 1989; 10: 509-14.

68. Payda $\triangle$ S, Zorludemir S, Sahin B. Vasculitis and leukemia. Leuk Lymphoma. 2000; 40: 105-12.

69. Mor F, Leibovici L, Wysenbeek AJ. Leukocytoclastic vasculitis in malignant lymphoma. Case report and review of the literature. Isr $\mathbf{J}$ Med Sci. 1987; 23: 829-32.

70. Gran JT, Sund S, Langholm R. Small cell pleomorphic T-cell lymphoma presenting with cutaneous vasculitis. Clin Rheumatol. 1994; 13: 628-30.

71. Farrell AM, Stern SC, El-Ghariani K, et al. Splenic lymphoma with villous lymphocytes presenting as leucocytoclastic vasculitis. Clin Exp Dermatol. 1999; 24: 19-22.

72. Castro M, Conn DL, Su WP, Garton JP. Rheumatic manifestations in myelodysplastic syndromes. J Rheumatol. 1991; 18: 721-7.

73. Green AR, Shuttleworth D, Bowen DT, Bentley DP. Cutaneous vasculitis in patients with myelodysplasia. Br J Haematol. 1990; 74: 364-5.

74. Patel AM, Davila DG, Peters SG. Paraneoplastic syndromes associated with lung cancer. Mayo Clin Proc. 1993; 68: 278-87.

75. Hutson TE, Hoffman GS. Temporal concurrence of vasculitis and cancer: a report of 12 cases. Arthritis Care Res. 2000; 13: 417-23.

76. Minakuchi K, Fujimoto K, Takada K, et al. Hepatocellular carcinoma associated with polyarteritis nodosa with symptoms appearing after intra-arterial chemotherapy. Br J Radiol. 1991; 64: 272-5.

77. Paajanen H, Heikkinen M, Tarvainen R, et al. Anaplastic colon carcinoma associated with necrotizing vasculitis. J Clin Gastroenterol. 1995; 21: 168-9.

78. Hommel C, Rihova Z, Mokaddem F, Libotte B. pANCA-vasculitis associated with rectal adenocarcinoma. Acta Clin Belg. 2014; 69: 463-6.

79. Hayem G, Gomez MJ, Grossin M, et al. Systemic vasculitis and epithelioma. A report of three cases with a literature review. Rev Rhum Engl Ed. 1997; 64: 816-24.

80. Beji M, Khedher I, Ayadi N, et al. Periarteritis nodosa associated with lung cancer. A new observation. Tunis Med. 1999; 77: 585-8.

81. Okada M, Suzuki K, Hidaka T, et al. Polyarteritis associated with hypopharyngeal carcinoma. Intern Med. 2002; 41: 892-5.

82. Gerber MA, Brodin A, Steinberg D, et al. Periarteritis nodosa, Australia antigen and lym- 
phatic leukemia. N Engl J Med. 1972; 286: 14-7.

83. Elkon KB, Hughes GR, Catovsky D, et al. Hairy-cell leukaemia with polyarteritis nodosa. Lancet. 1979; 2: 280-2.

84. Hughes GR, Elkon KB, Spiller R, et al. Polyarteritis nodosa and hairy-cell leukaemia. Lancet. 1979; 1: 678.

85. Hamidou MA, Boumalassa A, Larroche C, et al. Systemic medium-sized vessel vasculitis associated with chronic myelomonocytic leukemia. Semin Arthritis Rheum. 2001; 31: 119-26.

86. Vankalakunti M, Joshi K, Jain S, et al. Polyarteritis nodosa in hairy cell leukaemia: an autopsy report. J Clin Pathol. 2007; 60: 1181-2.

87. Saif MW, Hopkins JL, Gore SD. Autoimmune phenomena in patients with myelodysplastic syndromes and chronic myelomonocytic leukemia. Leuk Lymphoma. 2002; 43: 2083-92.

88. Araki R, Shima T, Goto H, et al. Wegener's granulomatosis with papillary adenocarcinoma of the thyroid. Intern Med. 1992; 31: 1065-8.

89. Liozon E, Loustaud V, Fauchais AL, et al. Concurrent temporal (giant cell) arteritis and malignancy: report of 20 patients with review of the literature. J Rheumatol. 2006; 33: 1606-14.

90. Speed CA, Haslock I. Polymyalgia rheumatica, temporal arteritis and malignancy. Postgrad Med J. 1995; 71: 500-2.

91. Espinosa G, Font J, Muñoz-Rodríguez FJ, et al. Myelodysplastic and myeloproliferative syndromes associated with giant cell arteritis and polymyalgia rheumatica: a coincidental coexistence or a causal relationship? Clin Rheumatol. 2002; 21: 309-13.

92. Gonzalez-Gay MA, Lopez-Diaz MJ, Martinez-Lado L, et al. Cancer in biopsy-proven giant cell arteritis. A population-based study. Semin Arthritis Rheum. 2007; 37: 156-63.

93. Kermani TA, Schäfer VS, Crowson CS, et al. Malignancy risk in patients with giant cell arteritis: a population-based cohort study. Arthritis Care Res (Hoboken). 2010; 62: 149-54.

94. Naschitz JE. Rheumatic syndromes: clues to occult neoplasia. Curr Opin Rheumatol. 2001; 13: 62-6.

95. Baka Z, Barta P, Losonczy G, et al. Specific expression of PAD4 and citrullinated proteins in lung cancer is not associated with anti-CCP antibody production. Int Immunol. 2011; 23: 405-14.

96. Chaun H, Robinson CE, Sutherland WH, Dunn WL. Polyarthritis associated with gastric carcinoma. Can Med Assoc J. 1984; 131: 909-11.

97. Stummvoll GH, Aringer M, Machold KP, et al. Cancer polyarthritis resembling rheumatoid arthritis as a first sign of hidden neoplasms. Report of two cases and review of the literature. Scand J Rheumatol. 2001; 30: 40-4.
98. Virshup AM, Sliwinski AJ. Polyarthritis and subcutaneous nodules associated with carcinoma of the pancreas. Arthritis Rheum. 1973; 16: 388-92.

99. Pines A, Kaplinsky N, Olchovsky D, Frankl O. Rheumatoid arthritis-like syndrome: a presenting symptom of malignancy. Report of 3 cases and review of the literature. Eur $\mathbf{J}$ Rheumatol Inflamm. 1984; 7: 51-5.

100. Eggelmeijer F, Macfarlane JD. Polyarthritis as the presenting symptom of the occurrence and recurrence of a laryngeal carcinoma. Ann Rheum Dis. 1992; 51: 556-7.

101. Bennett RM, Ginsberg MH, Thomsen S. Carcinomatous polyarthritis. The presenting symptom of an ovarian tumor and association with a platelet activating factor. Arthritis Rheum. 1976; 19: 953-8.

102. Gur H, Koren V, Ehrenfeld M, et al. Rheumatic manifestations preceding adult acute leukemia: characteristics and implication in course and prognosis. Acta Haematol. 1999; 101: 1-6.

103. Evans TI, Nercessian BM, Sanders KM. Leukemic arthritis. Semin Arthritis Rheum. 1994; 24: 48-56.

104. Barnes L, Rodnan GP, Medsger TA, Short D. Eosinophilic fasciitis. A pathologic study of twenty cases. Am J Pathol. 1979; 96: 493-518.

105. Manzini CU, Dotoli R, Villani M, Mascia MT, Manzini E. La fasciite eosinofila: contributo casistico (Considerazioni patogenetiche e nosografiche). Boll Soc Med Chir Modena. 1986; 86: 53-62.

106. Giordano M, Ara M, Cicala C, Valentini G, Chianese U, Vatti M. Eosinophilic fasciitis. Ann Intern Med. 1980; 93: 645-6.

107. Kent LT, Cramer SF, Moskowitz RW. Eosinophilic fasciitis: clinical, laboratory, and microscopic considerations. Arthritis Rheum. 1981; 24: 677-83.

108. Lakhanpal S, Ginsburg WW, Michet CJ, et al. Eosinophilic fasciitis: clinical spectrum and therapeutic response in 52 cases. Semin Arthritis Rheum. 1988; 17: 221-31.

109. Kennedy C, Leak A. Eosinophilic fasciitis with erosive arthritis. Clin Exp Dermatol. 1982; 7: 469-76.

110. Khanna D, Verity A, Grossman JM. Eosinophilic fasciitis with multiple myeloma: a new haematological association. Ann Rheum Dis. 2002; 61: 1111-2.

111. Masuoka H, Kikuchi K, Takahashi S, et al. Eosinophilic fasciitis associated with lowgrade T-cell lymphoma. $\mathrm{Br} \mathrm{J}$ Dermatol. 1998; 139: 928-30.

112. Michaels RM. Eosinophilic fasciitis complicated by Hodgkin's disease. J Rheumatol. 1982; 9: 473-6.

113. Resnick D. Reumatismo articolare acuto. In: Resnick D, Niwayama G. Patologia diagnos- 
tica dell'apparato locomotore. Vol II, Cap 38. Ed. Verduci. 1985; 1265-74.

114. Johnson JJ, Leonard-Segal A, Nashel DJ. Jaccoud's-type arthropathy: an association with malignancy. J Rheumatol. 1989; 16: 1278-80.

115. Brouet JC, Clauvel JP, Danon F, et al. Biologic and clinical significance of cryoglobulins. A report of 86 cases. Am J Med. 1974; 57: 775-88.

116. Ferri C, Zignego AL, Pileri SA. Cryoglobulins. J Clin Pathol. 2002; 55: 4-13.

117. Ramos-Casals M, Stone JH, Cid MC, Bosch X. The cryoglobulinaemias. Lancet. 2012; 379: 348-60.

118. Ferri C, La Civita L, Longombardo G, et al. Mixed cryoglobulinaemia: a cross-road between autoimmune and lymphoproliferative disorders. Lupus. 1998; 7: 275-9.

119. Dammacco F, Sansonno D, Piccoli C, et al. The cryoglobulins: an overview. Eur J Clin Invest. 2001; 31: 628-38.

120. Ferri C, Sebastiani M, Giuggioli D, et al. Mixed cryoglobulinemia: demographic, clinical, and serologic features and survival in 231 patients. Semin Arthritis Rheum. 2004; 33: 355-74.

121. Saadoun D, Sellam J, Ghillani-Dalbin P, et al. Increased risks of lymphoma and death among patients with non-hepatitis $\mathrm{C}$ virusrelated mixed cryoglobulinemia. Arch Intern Med. 2006; 166: 2101-8.

122. Shiel WC Jr, Prete PE, Jason M, Andrews BS. Palmar fasciitis and arthritis with ovarian and non-ovarian carcinomas. New syndrome. Am J Med. 1985; 79: 640-4.

123. Veitch D, Tsai T, Joshua F. Palmar fasciitis and polyarthritis syndrome in pancreatic carcinoma. J Clin Rheumatol. 2013; 19: 203-5.

124. Todesco S, Gambari PF. Malattie reumatiche. Milano: Mc Graw Hill Italia. 1993; 276.

125. González-Gay MA, García-Porrúa C, Salvarani $\mathrm{C}$, et al. Polymyalgia manifestations in different conditions mimicking polymyalgia rheumatica. Clin Exp Rheumatol. 2000; 18: 755-9.

126. Naschitz JE, Slobodin G, Yeshurun D, et al. Atypical polymyalgia rheumatica as a presentation of metastatic cancer. Arch Intern Med. 1997; 157: 2381.

127. Mertens JC, Willemsen G, Van Saase JL, et al. Polymyalgia rheumatica and temporal arteritis: a retrospective study of 111 patients. Clin Rheumatol. 1995; 14: 650-5.

128. Niccoli L, Salvarani C, Baroncelli G, et al. Renal cell carcinoma mimicking polymyalgia rheumatica. Clues for a correct diagnosis. Scand J Rheumatol. 2002; 31: 103-6.

129. Nashitz JE, Rosner I, Rozenbaum M, et al. Cancer-associated rheumatic disorders: clues to occult neoplasia. Semin Arthritis Rheum. 1995; 24: 231-41.
130. Virshup AM, Sliwinski AJ. Polyarthritis and subcutaneous nodules associated with carcinoma of the pancreas. Arthritis Rheum. 1973; 16: 388-92.

131. Hughes SH, Apisarnthanarax P, Mullins F. Subcutaneous fat necrosis associated with pancreatic disease. Arch Dermatol. 1975; 111: 506-10.

132. Naschitz JE, Yeshurun D, Dreyfuss U, et al. Localized nodular myositis. A paraneoplastic phenomenon. Clin Rheumatol. 1992; 11: 427-31.

133. Bhatnagar D, Carey P, Pollard A. Focal myositis and elevated creatine kinase levels in a patient with phaeochromocytoma. Postgrad Med J. 1986; 62: 197-8.

134. McLendon CL, Levine PA, Mills SE, Black WC. Squamous cell carcinoma masquerading as focal myositis of the tongue. Head Neck. 1989; 11: 353-7.

135. Ginburg WW, O’Duffy D, Morris JL, Huston KA. Multicentric reticulohistiocytosis: response to alkylating agents in six patients. Ann Int Med. 1989; 111: 384.8.

136. Resnick D. Lipidosi, istiocitosi e iperliproteinemie. In: Resnick e Niwayama. Patologia e diagnostica dell'apparato locomotore. Vol III, Cap 57. Ed. Verduci. 1986; 1963-2005.

137. Nunnink JC, Krusinski PA, Yates JW. Multicentric reticulohistiocytosis and cancer: a case report and review of the literature. Med Ped Oncol. 1985; 13: 273-9.

138. Barrow MV, Holubar K. Multicentric reticulohistiocytosis. A review of 33 patients. Medicine (Baltimore). 1969; 48: 287-305.

139. Fast A. Cardiopulmonary complications in multicentric reticulohistiocytosis. Report of a case. Arch Dermatol. 1976; 112: 1139-41.

140. Goltz RW. Multicentric reticuloistiocytosis. Arch Dermatol. 1964; 89: 639.

141. Warin RP, Evans CD, Hewitt M, et al. Reticulohistiocytosis (lipoid dermato-arthritis). Br Med J. 1957; 1: 1387-91.

142. Korthaus A. A case of fatal reticulohistiocytosis. Z Haut Geschlechtskr. 1972; 47: 875-80.

143. Granelli U, Bignami A, Nazzaro P. Giant cell reticulohistiocytosis (lipoid dermatoarthritis). anatomo-clinical study of 2 cases). G Ital Dermatol. 1963; 104: 285-306.

144. Ridgway HA, Rhodes EL. Multicentric reticulohistiocytosis with carcinoma-in-situ of the cervix. Br J Dermatol. 1979; 101: 61-2.

145. Goltz RW, Laymon CW. Multicentric reticulohistiocytosis of the skin and synovia; reticulohistiocytoma or ganglioneuroma. AMA Arch Derm Syphilol. 1954; 69: 717-31.

146. Hall-Smith P. Multicentric reticulohistiocytosis with ovarian carcinoma. Proc R Soc Med. 1976; 69: 380-1.

147. Takubo H, Hanaoka K, Shimizu N, et al. Case of unusual leukemic reticulosis pos- 
sibly derived from multicentric reticulohistiocytosis. Saishin Igaku. 1970; 25: 2623-37.

148. David-Chaussé J, Dehais J, Picot C, Bullier R. Multicentric reticulohistiocytosis (lipoid dermato-arthritis). Apropos of a case with fatal outcome. Rev Rhum Mal Osteoartic. 1976; 43: 123-32.

149. Catterall MD. Multicentric reticulohistiocytosis: a review of eight cases. Clin Exp Dermatol. 1980; 5: 267-79.

150. Delèvaux I, Cabane J, Le Nechet E, et al. A paraneoplastic acrosyndrome. Presse Med. 1999; 28: 1109-11.

151. Schildmann EK, Davies AN. Paraneoplastic Raynaud's phenomenon--good palliation after a multidisciplinary approach. J Pain Symptom Manage. 2010; 39: 779-83.

152. Poszepczynska-Guigne' E, Viguier M, Chosidow $\mathrm{O}$, et al. Paraneoplastic acral vascular syndrome: epidemiologic features, clinical manifestations, and disease sequelae. J Am Acad Dermatol. 2002; 47: 47-52.

153. DeCross AJ, Sahasrabudhe DM. Paraneoplastic Raynaud's phenomenon. Am J Med. 1992; 92: 571-2.

154. Taillan B, Castanet J, Garnier G, et al. Paraneoplastic Raynaud's phenomenon. Clin Rheumatol. 1993; 12: 281-2.

155. Kohli M, Bennett RM. Raynaud's phenomenon as a presenting sign of ovarian adenocarcinoma. J Rheumatol. 1995; 22: 1393-4.

156. Abu-Shakra M, Buskila D, Ehrenfeld M, et al. Cancer and autoimmunity: autoimmune and rheumatic features in patients with malignancies. Ann Rheum Dis. 2001; 60: 433-41.

157. Hill CL, Zhang Y, Sigurgeirsson B, et al. Frequency of specific cancer types in dermatomyositis and polymyositis: a populationbased study. Lancet. 2001; 357: 96-100.

158. Benedek TG. Neoplastic associations of rheumatic diseases and rheumatic manifestations of cancer. Clin Geriatr Med. 1988; 4: 333-55.

159. Caldwell IW. A dermatomyositic symptomcomplex associated with malignant disease. Br J Cancer. 1955; 9: 575-81.

160. Callen JP. When and how should the patient with dermatomyositis or amyopathic dermatomyositis be assessed for possible cancer? Arch Dermatol. 2002; 138: 969-71.

161. Zantos D, Zhang Y, Felson D. The overall and temporal association of cancer with polymyositis and dermatomyositis. J Rheumatol. 1994; 21: 1855-9.

162. Jablonska S, Blaszczyk M. Scleroderma-like disorders. Semin Cutan Med Surg. 1998; 17: 65-76.

163. Bielefeld P. Systemic scleroderma and malignant diseases. A review of the literature. Rev Med Interne. 1991; 12: 350-4.

164. Querfeld C, Sollberg S, Huerkamp C, et al.
Pseudoscleroderma associated with lung cancer: correlation of collagen type I and connective tissue growth factor gene expression. Br J Dermatol. 2000; 142: 1228-33.

165. Enzenauer RJ, McKoy J. Case report: rapidly progressive systemic sclerosis associated with carcinoma of the lung. Milit Med. 1993; 154: 574-7.

166. Ciołkiewicz M, Domysławska I, Ciołkiewicz A, et al. Coexistence of systemic sclerosis, scleroderma-like syndromes and neoplastic diseases. Pol Arch Med Wewn. 2008; 118: 119-26.

167. Patel AM, Davila DG, Peters SG. Paraneoplastic syndromes associated with lung cancer. Mayo Clin Proc. 1993; 68: 278-87.

168. Colaci M, Giuggioli D, Vacchi C, et al. Breast cancer in systemic sclerosis: results of a cross-linkage of an Italian Rheumatologic Center and a population-based Cancer Registry and review of the literature. Autoimmun Rev. 2014; 13: 132-7.

169. Strickland RW, Limmani A, Wall JG, Krishnan J. Hairy cell leukemia presenting as a lupus-like illness. Arthritis Rheum. 1988; 31: 566-8.

170. Freundlich B, Makover D, Maul GG. A novel antinuclear antibody associated with a lupus-like paraneoplastic syndrome. Ann Intern Med. 1988; 109: 295-7.

171. Chtourou M, Aubin F, Savariault I, et al. Digital necrosis and lupus-like syndrome preceding ovarian carcinoma. Dermatology. 1998; 196: 348-9.

172. Carsons S. The association of malignancy with rheumatic and connective tissue diseases. Semin Oncol. 1997; 24: 360-72.

173. Wallach HW. Lupus-like syndrome associated with carcinoma of the breast. Arch Intern Med. 1977; 137: 532-5.

174. Menon S, Snaith ML, Isenberg DA. The association of malignancy with SLE: an analysis of 150 patients under long-term review. Lupus. 1993; 2: 177-81.

175. Caldwell DS, McCallum RM. Rheumatologic manifestations of cancer. Med Clin North Am. 1986; 70: 385-417.

176. McCarty GA. Autoimmunity and malignancy. Med Clin North Am. 1985; 69: 599-615.

177. Manger B, Schett G. Paraneoplastic syndromes in rheumatology. Nat Rev Rheumatol. 2014; 10: 662-70.

178. Chong WH, Molinolo AA, Chen CC, Collins MT. Tumor-induced osteomalacia. Endocr Relat Cancer. 2011; 18: R53-77.

179. Folpe AL, Fanburg-Smith JC, Billings SD, et al. Most osteomalacia-associated mesenchymal tumors are a single histopathologic entity: an analysis of 32 cases and a comprehensive review of the literature. Am J Surg Pathol. 2004; 28: 1-30. 